Article

\title{
Revisiting Ecosystem Services: Assessment and Valuation as Starting Points for Environmental Politics
}

\author{
Adam Jadhav 1,* (D), Sharolyn Anderson ${ }^{2}$, Michael J. B. Dyer ${ }^{2}$ and Paul C. Sutton ${ }^{3}$ \\ 1 Department of Geography, University of California at Berkeley, Panchabhuta Conservation Foundation, \\ Berkeley, CA 94701, USA \\ 2 School of Natural and Built Environments, University of South Australia, Adelaide, SA 5006, Australia; \\ sharolyn.anderson@unisa.edu.au (S.A.); dyemj003@mymail.unisa.edu.au (M.J.B.D.) \\ 3 Department of Geography, University of Denver, Denver, CO 80208, USA; paul.sutton@du.edu \\ * Correspondence: ajadhav@berkeley.edu; Tel.: +1-623-252-3428
}

Received: 21 August 2017; Accepted: 26 September 2017; Published: 28 September 2017

\begin{abstract}
The paradigm of ecosystem services (ES) and the methods of monetary valuation have become boundary objects, spanning disciplines and earning particular purchase in policy circles. However, the notion of ES and ES valuation have also been subjected to multiple critiques, ranging from their varying precision to the potential for neoliberalization of nature. This paper does not attempt to refute such critiques but rather revisits the potentials of the ES paradigm and the specific method of benefit transfer valuation for their utility as a form of environmental politics and sustainability practice. We find they have particular relevance in contexts where "data" are not readily available or are not legible to policy makers as well as where the imperative of "development" remains ideological. We argue for ES assessment and, specifically, rapid ES valuation as a first-pass tactic to inform evaluation of potentially environmentally degrading projects or environmental management. We demonstrate this using a simple benefit transfer analysis to offer an initial evaluation of (wet) landscape ES in a lightly touched estuary in Karnataka, India, where a state-backed proposal to develop an industrial shipping port is gathering steam. While we recognize and do not categorically reject critiques of the ES paradigm, we nonetheless argue for valuation as a starting point for politics that highlight and make visible ES benefits and users implicated by "development" and other kinds of environmental change.
\end{abstract}

Keywords: ecosystem services; valuation; benefit transfer; sustainable development; environmental politics; remote sensing; India

\section{Introduction}

For decades, trends in forest cover loss, land use change, marine ecosystem degradation and declining environmental health, particularly in the Global South, have rung alarm bells [1-3]. While questions about material human impacts on the earth are certainly not new [4], scholars and policy makers increasingly recognize the scale of anthropogenic forces not only as isolated or regional [5] but also international [6]. These analyses have also been aided by the increased power of remote sensing technology and publicly available satellite imagery. Concurrently, discussion, debate and diagnosis of ecological change or degradation has been read through a framework highlighting "nature" as a provider of a plethora of valuable (even invaluable) ecosystem goods and services (hereafter referred to as ES) vital to human (and non-human) wellbeing. A typology of ES and new methods for categorization and measurement have developed particularly following influential publications in late 1990s and 2000s [7-9]. 
Today, the ES paradigm features prominently in policy, theoretical and activist discussions around environmental protection and critiques of development $[10,11]$, such that the ES concept may constitute a "boundary object" that readily bridges divides between policymakers, scholarly disciplines and laypeople [12,13]. Economic valuations of ES—often relying on neoclassical economics and natural resource accounting methods-have grown increasingly detailed while also gaining political and policy purchase. In particular, the Economics of Ecosystems and Biodiversity (TEEB) initiative, hosted by the United Nations Environment Programme, has helped "the real value of natural capital, and the flows of services it provides, to become visible and be mainstreamed in decision making" [14] (p. 24). Scholars have also produced global-scale economic valuations of ES in recognition of the real loss to landscapes, biodiversity, ecology and "natural capital" [15-17]. For example, in a widely cited 2014 estimate-which informs this paper's analysis-a team of scholars approximated that loss in annual global ES from 1997 to 2011 could be as much as \$20 trillion [15]. More recently, the Intergovernmental Science-Policy Platform on Biodiversity and Ecosystem Services (IPBES)—an advising and assessment body established by national governments with functions akin to the Intergovernmental Panel on Climate Change- - has included ecosystem goods and services within a conceptual framework of nature (human and non-human), drivers of ecosystem change, institutions, governance and well-being (human and non-human) [18-20]. While the IPBES framework acknowledges multiple perspectives for understanding human and non-human natures, it also cements the ES paradigm as a key analytic.

Although a prominent frame in the policy-science interface, ES and ES valuation is not without controversy. Critics have argued that explicitly valuing "nature" may pave the way to pricing, marketing and commodification of environmental public goods [21,22]; furthermore, some critics charge that the process is rooted in a kind of environmental pragmatism that gives too much ground to economists [23] while overlooking methodological problems of measurement and imprecise valuation $[24,25]$. Benefit transfer, the method used in major global studies as well as this paper, has been critiqued for its limits-particularly its imprecision [26]. In addition, measuring the value of natural goods and functions has not always led to smooth and clear policy mechanisms [27] and even proponents of ES assessment and valuation admit that policy implementation or integration of ES into landscape planning remains a challenge [28]. Meanwhile, interpretation of remote sensing data-typically classification of land-cover uses or types-has also been criticized as both diverging from local opinions and having the potential to reduce or "fix" dynamic landscapes through reductionist characterizations [29].

We do not reference these critiques to either categorically defend or condemn ES, though we note that ES scholars themselves have responded to critics on various charges [13]. Consideration of the multiple values derived from ecosystems by humans and non-humans within them (see typology in [30]) makes clear that ES is hardly the only way to render or understand the functions and structures of ecosystems. We generally agree that monetary valuation in particular is a narrow form of valuing all that might be called "nature". We readily acknowledge that market prices (real or hypothetical) overlook a range of other values of ES, from their status as a bequest to future generations to the worth that ES have in, of and to themselves. Even those market prices that exist (e.g., the going rate for fish at the market) are likely conservative, when prices suffer from a political economy that discounts ES heavily and frequently does not account for so-called externalized costs to the use (or abuse) of "nature". This critique of the ES paradigm is sometimes extended to suggest that categorization and valuation flow from or reinforce neoliberal ideology; in this way, the ES paradigm may feed market-based conservation policies or support the creation of natural resource markets (often through appropriation) and the development of "neoliberal natures" [21,22,31-33]. This lengthy critique has considerable purchase but it is also not without its own debate [34,35].

In this paper, we certainly do not advocate for such market-led transformation of ES into commodities. We largely follow Costanza et al.:

"We want to make clear that expressing the value of ecosystem services in monetary units does not mean that they should be treated as private commodities that can be traded in 
private markets ... Even if fish and other provisioning services enter the market as private goods, the ecosystems that produce them (i.e., coastal systems and oceans) are common assets. Their value in monetary units is an estimate of their benefits to society expressed in units that communicate with a broad audience ... to inform better, more balanced decisions regarding trade-offs with policies that enhance GDP but damage ecosystem services" [15] (p. 157).

Rather, we see utility in applications of the ES paradigm and valuation as specific forms of politics intended to engage and inform decision-making about "development" as well as guide and enliven debates over sustainability in environmental management. We are sympathetic to political ecology critiques of ES and valuation - as well as conservation governance and sustainable development more broadly-as being exercises in power. Kull, de Sartre and Castro-Larrañaga note that ES and valuation have been imbued with multiple meanings that are context dependent-"simultaneously a technical, pedagogic, heuristic, policy, and political notion" [36] (p. 131)—and subject to different uses by a range of actors from the high modern state to social resistance movements. In other words, the deployment of the ES paradigm and valuation as a tool is deeply imbricated within political contexts where actors have asymmetric power relations. In addition, we remain cautious about the overzealous application of the ES paradigm and its potential, if applied inappropriately, to reduce complex ecological challenges by forcing all environmental use (and abuse) into oversimplified stock-flow frames [37]. Rather, we argue for the use of the ES paradigm and valuation within specific realms of politics and practice.

Finally, we note that, contemporary to the rise of the ES paradigm in the 1990s and 2000s, environmental management trended toward a focus on local governance, decentralization, participatory and so-called bottom-up approaches. This renewed focus on the local saw strong international articulation in the context of the U.N. Conference on Environmental and Development in Rio as "participation" was enshrined in the resulting international declaration. Meanwhile, scholarship surrounding governance of the environmental commons-including celebrated work by Ostrom [38] - further interlinked the idea of sustainable resource management with local control, subsidiarity and insulation from external pressures. Moreover, both left-leaning critiques of the state [39] as well as right-leaning neoliberal theory predict that top-down management of conservation and development would be prone to failure; this is particularly to be expected when managers have little downward accountability to resource users who face the brunt of impacts-positive or negative-from environmental regulations and projects. A focus on locally led conservation can also be understood as a response to data-poor contexts where local knowledge could better govern ecologies that were illegible to management from on-high. However, with increasing public availability of remote-sensing imagery—-such as is used in this paper-the meaning of data-poor conservation should be interrogated [40].

This paper steps into the space between the ES paradigm - particularly as it is sometimes rendered an analytic for cataloguing, measuring and ultimately commodifying nature-and environmental management discourse that privileges the local, particularly in the absence of other kinds of ecological data. We see ES mapping and valuation not as an automatic move to commodify but, rather, as a tool having the potential to inform local processes of environmental politics and decision making. First-pass ES analyses may provide a bridge between recognizing dependency on natural resources and sustainably managing those resources [41]. We suggest ES valuation as particularly useful in the specific consideration of "development" that drifts into the ideological terrain of neoclassical growth economics and accounting. We argue for the identification and first-pass valuation of ES on a local scale as a specific form of environmental politics, dialogue and advocacy. We see this as one way to open space for critical evaluation of "development" and discussion of sustainable environmental use. In doing so, we also believe we stay closer to the early aims of scholars developing the ES paradigm and valuation exercises by emphasizing the heuristic and political relevance of valuation exercises in specific contexts.

To demonstrate what we envision, we now present an ecosystem service valuation using a benefit transfer model of a shallow coastal estuarine landscape in southwestern India. We end by returning to 
a discussion of what we see as the utility of the ES paradigm and ES valuation as a specific kind of environmental political practice; as an example, we discuss specifically how the results can be applied and wielded as part of a larger engagement with local and regional NGOs and activists. First, however, we present social, economic, ecological and political context for the study area.

\section{Study Context}

India's pro-growth economic development has taken a mounting toll on environmental health and ES [42-44]. Coastal spaces and places-often the commons-in particular are beset by contentious transformations of land use, planning, development, notions of ownership and resource tenure [45-48]. The combination of environmental degradation in many places-coupled with urban development biases and rural economic stagnation - has also contributed to the wider trend of migration to cities [49]. For example, in coastal areas, rural fishing communities are increasingly depleted of labor, at least seasonally, as individual fishermen seek work in large cities-either in ports as boat and dockhands or in the wider urban economy.

In this paper, we report the ES valuation of the core extent of the Aghanashini River estuary, a relatively undisturbed riparian and wetland ecosystem on India's west coast in the state of Karnataka (Figure 1). The Aghanashini River estuarine region represents a hyper-diverse, socially critical ecology [50]. More than 14,000 households (approximately 64,000 people) live in villages and hamlets bordering the estuary; the administrative area encompassing the estuary (known as a Kumta Taluk) has a total rural population of more than 117,000 [51]. Though the nearby semi-urban town of Kumta increasingly serves as an employment hub, a large portion of households living near the estuary remain at least partially dependent on estuarine ES for sustenance and livelihoods such as fishing, farming, resource gathering and related secondary employment. Local ecology also provides various other services, including erosion/flood control, water filtration, protection from adverse weather and adjustment of microclimate. Many of these ES are expressly acknowledged in our interviews and other ongoing research with community members [52].

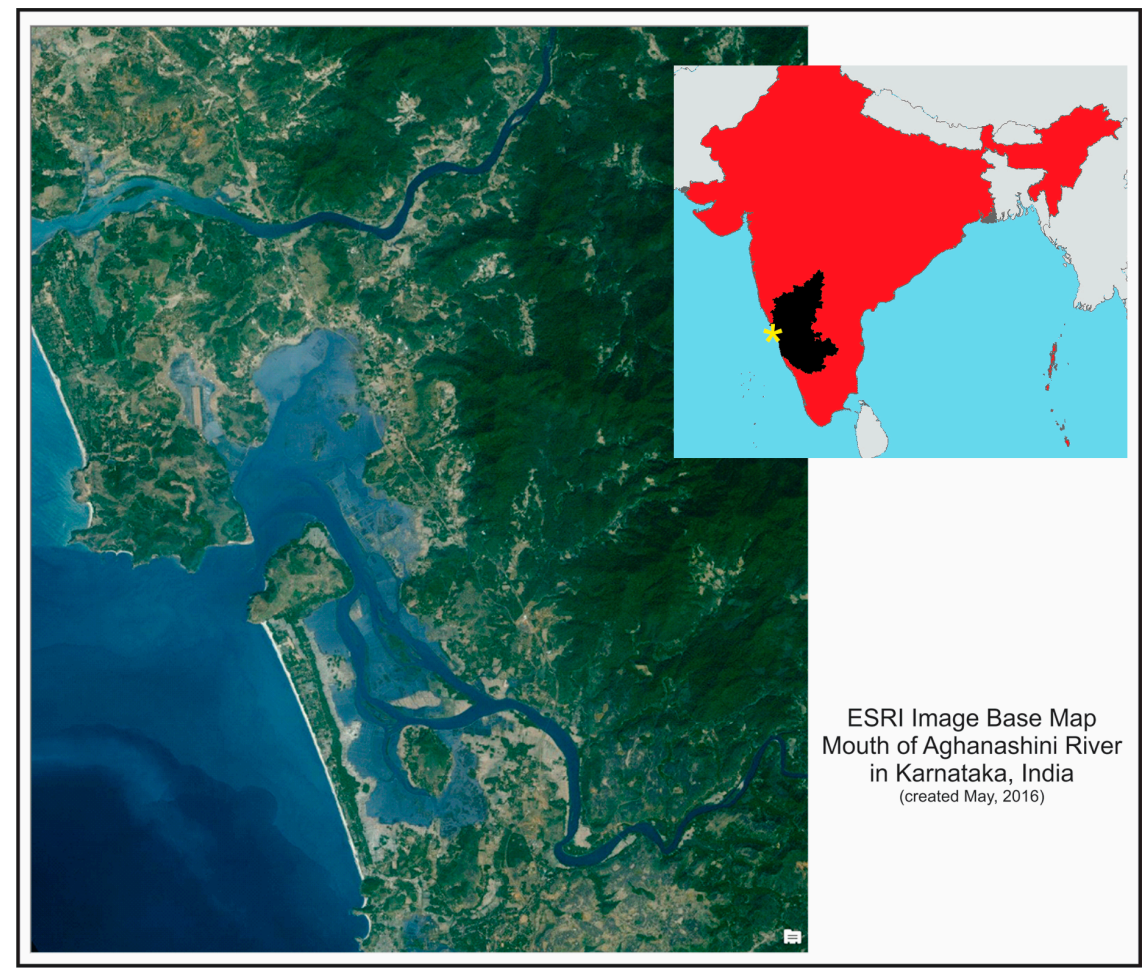

Figure 1. Location map of ecosystem service (ES) valuation study area. 
The estuary is the outlet of the Aghanashini River and its many tributaries that cover a watershed stretching into the biodiverse Western Ghats. The river near Kumta town begins to braid among islands, mangrove patches, floodplains and wetlands before opening into a wide estuary with tidal mudflats. Eleven species of mangroves and more than 30 other mangrove associates extensively cover river and field edges [53]; their extent is actually increasing due in part to aggressive plantation efforts of government, civil society and some citizens. More than 100 species of birds are recorded in the estuary [50]; small-scale fishers in the river catch nearly 80 species of fish [54]; and a vibrant bivalve fishery supports substantial clam, oyster and mussel trade and local consumption [55].

The estuary also provides a nursery ground for marine species that end up in the nets of open-ocean trawl and purse seine boats that also dock within the estuary. The backwaters are also interconnected to submerged fields and ponds known as gajni land, used traditionally for a mix of fishing, aquaculture and cultivation of salt-tolerant rice. Local unemployment approaches $60 \%$ according to some calculations [51], though many people "work" in subsistence economies and household production outside official employment measurement. Present livelihoods provide standards of living better than much of rural and coastal India. Some fishers within the estuary report that they do not yet face scarcity, and abject poverty is mostly absent. The river also feeds the saline reservoirs of large cooperative and privately owned saltpan operations. Gokarna town, north of the estuary, is known for tourists, temples and beaches, though tourism within the estuary-boating or viewing wildlife around mangroves, for example-is scarce.

While any narrative of pristine nature can be questioned from an environmental history perspective [56], we describe the estuary as lightly touched. The Aghanashini is one of India's few remaining undammed rivers and no heavy industry or large cities exist on its banks. Local livelihoods do interact with and change the river, but alterations of an industrial scale are not observed. The level of biodiversity within the estuary, coupled with high ES dependence, has motivated multiple civil society and scholarly proposals for institutional protection under different Indian legal frameworks. However, these proposals have garnered little administrative or political support.

This picture is hardly static. Cyclical ecological variation and long-term climate change will force ecosystem and residential shifts. Interviews also reveal an external political economy and poverty alleviation discourse that drive social, economic and ecological changes [42,57]. Public and private actors increasingly promote new neoliberal development forms and economic activities. For example, substantial tracts of gajni land were converted to permanent shrimp ponds in the 1990s only to be abandoned when the sector collapsed due to unsustainability; today, investors are now repurposing these submerged fields for other forms of high modern aquaculture. Dredging and "mining" the river bottom for shells and sand-used in construction - have also become contentious forms of river use.

The largest source of potential change or disruption in the estuary, however, is a controversial proposed industrial shipping port, zealously backed by the Karnataka state government's industrial development promotion arm. The proposal calls for landfilling a large portion of estuarine shallows for dock construction, while other portions of the estuary would be dredged from a current depth of less than a meter to 16 or $18 \mathrm{~m}$ of depth to accommodate large coal and iron freighters. The project would clear or pollute dozens of hectares of natural mangroves, mangrove plantation, fishing grounds, bivalve mudflats and salt pans. Proponents admit a high likelihood of declines in water quality-including riparian flows that feed farm fields-and potential socio-economic disturbance throughout the region [58].

In return, project promoters promise temporary jobs in port construction for local people (while also acknowledging that long-term management and operations at the port will likely be given to outsiders with higher education levels). Some secondary employment-for example, truck repair or petty shops and restaurants to serve new port employees-is also expected, yet significantly more livelihood loss is likely due to foreclosure of current natural resource occupations including fishing, bivalve collection and salt-panning; government analysts admit as much when they suggest a need for compensation for livelihood displacement [58]. In interviews, some residents express support for 
this kind of industrial "development", which they feel has been denied to the region; others oppose it because of social and environmental impacts. Both positions are colored by specific histories of land accumulation and social ecological traditions [59]. Local and outside activists meanwhile accuse the government of paying lip-service to supposed democratic and environmental regulatory checks such the mandatory Environmental Impact Assessment (EIA) [60].

The port project and an ancillary railroad extension continue to move through the central government environmental clearance process. Such projects in India are subject to a regulatory framework governing coastal commons, though actual environmental management remains weak, fractured or nonexistent [57]. The signature national rule, the Coastal Regulation Zone (CRZ) Notification, theoretically limits development in ecologically sensitive areas and gives dependent communities a voice in environmental management [61]. However, the CRZ is routinely flouted; monitoring and enforcement are absent; and community participation is often an afterthought. Other laws apply to aspects of the coastal commons-e.g., rules governing aquaculture or fisheries-but these are routinely ignored or unenforced. This is not uncommon across India where policymakers often revert to a development vs. environment dichotomy [62] in which "development" routinely is an ideological winner. As such, the port project is political as well as material; not surprisingly, it is the target of ongoing political contest for and against from local, regional and national actors.

Environmental management-or even weighing potential tradeoffs of a development project such as the proposed port in the Aghanashini estuary-is also hampered particularly by a lack of social and ecological data. Baseline data and mapping has improved some in recent years with particular emphasis on government remote sensing applications [63], yet these activities have been contested by civil society actors on the grounds that they contain politically motivated flaws [64]. Although not a commonplace method, ES study and valuation has been conducted in a variety of Indian cases e.g., [65-68]; indeed, some Indian data has contributed to the global ES value database produced by the TEEB project [69] used in this paper. Meanwhile, conservation scientists have argued for a long list of overlooked or understudied aspects of marine and coastal ecology and biology in India [70]. An EIA is mandated by law for many intensive "development" projects-including the proposed shipping port-yet such reports are frequently challenged on the grounds that they lack basic facts or contain severe inaccuracies [71]. Various environmental regulations-such as coastal zone rules even now being rewritten by the central government with an eye to easing regulatory hurdles-suffer not only from a lack of data for implementation but also political will; in a sense, the data-poor regulatory environment obscures or elides political motivations in evaluating "development" or sustainability tradeoffs. In the absence of more robust environmental data (as well as politics), Johannes' argument for "data-less management" [72] dependent on local insight gains relevance. An interesting contemporary example highlights fisher communities in southeastern India blending traditional ecological knowledge with increasingly available satellite data to challenge state maps and development plans that ignore or overlook critical natural resources and dependent communities [73].

This is the context of environmental politics and debates over development in India generally and the Aghanashini River estuary specifically, which we argue can be informed by the ES valuation method we now present.

\section{Materials and Methods}

We use a simple ES valuation method known as benefit transfer. First, we measure the areal extent of a variety of land covers and then apply a per hectare ES value for biomes corresponding to the land covers identified. We note that this is rather straightforward practice; our intent in this paper is not methodological innovation per se but an argument for this method as political practice.

Our valuation exercise relies on satellite imagery captured of the Aghanashini River estuary on 28 April 2015 by the WorldView-3 imaging satellite [74] and Landsat 8 imagery captured on 1 April 2015 (Table 1). In addition, we rely on a larger set of formal and informal interviews with residents and experts to help explain ecological, social and economic context as well as physical 
geography [52]. We used biome values (corresponding to classified land covers) derived from the TEEB database [69], which contains more than 1350 data points from more than 300 peer-reviewed case studies. These estimates are the same values used by Costanza et al. in their 2014 global ES assessment [15].

Table 1. Summary of imagery.

\begin{tabular}{ccc}
\hline Parameters & Landsat 8 OLI & WorldView-3 \\
\hline Spatial Resolution & $30 \mathrm{~m}$ & $1.24 \mathrm{~m}$ \\
Spectral Window & $0.433-2.3 \mu \mathrm{m}$ & $0.400-1.040 \mu \mathrm{m}$ \\
Number of Bands & 8 & 8 \\
Radiometric Resolution & $16 \mathrm{bit}$ & $11 \mathrm{bit}$ \\
Date of Acquisition & 1 April 2015 & 28 April 2015 \\
\hline
\end{tabular}

\subsection{Land-Cover Classification}

We perform a land-cover classification using a mixed method classification approach, which involved a maximum likelihood classification workflow with selected training sites (Figure 2). There was significant spectral variation of the ocean and estuary, which we masked in total as either "marine shelf" or "estuary" (Figure 3). We accomplished this using a digitized boundary created with expert local knowledge and the $31 \mathrm{~cm}$ resolution panchromatic WorldView-3 image. We used the same approach for the Landsat 8 imagery.

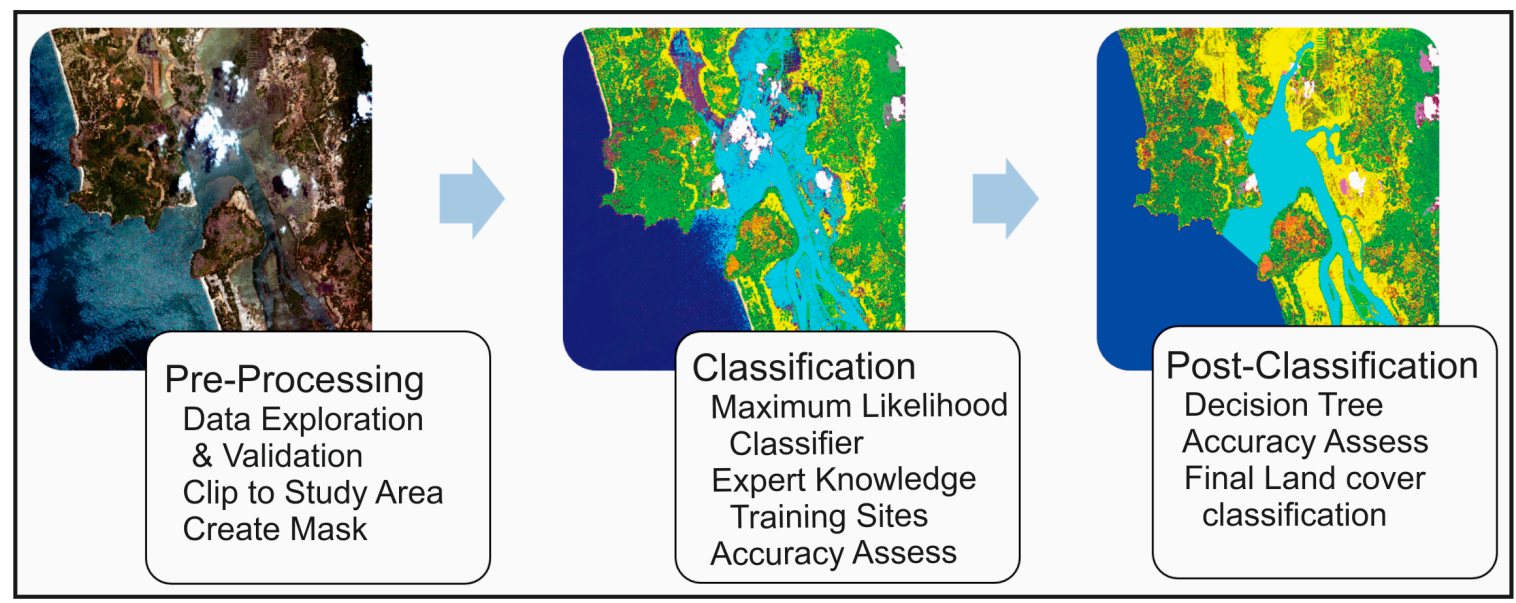

Figure 2. Image processing flow chart.
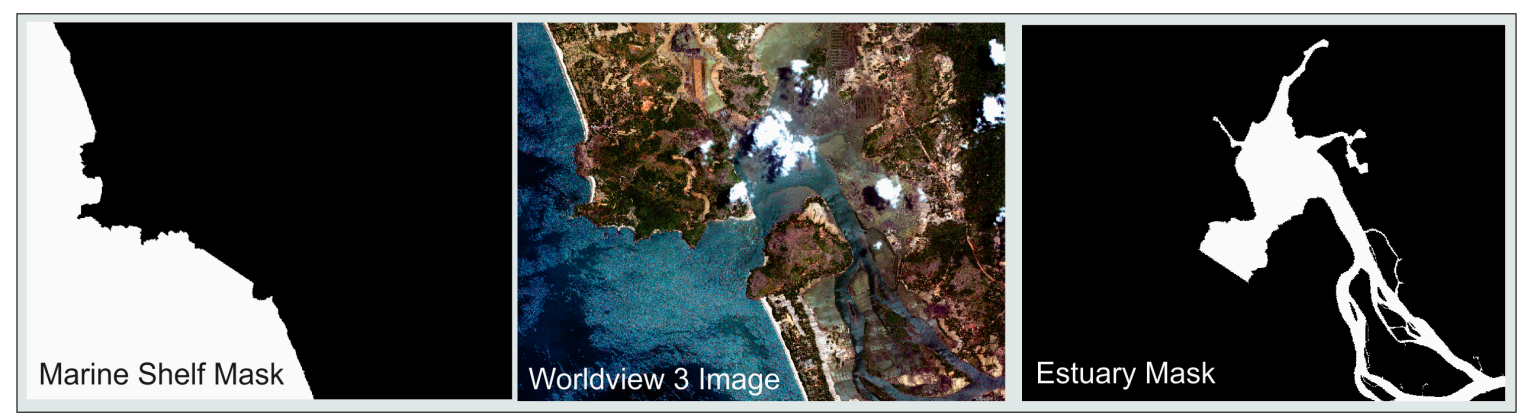

Figure 3. Masks for marine shelf and estuary used in decision tree classifier.

In the scene, there is a large amount of fishing, aquaculture and farming in flooded rice fields-the gajni land. The spectral reflectance of these areas was indistinguishable from those of the estuary, 
yet their ES value is more similar to cropland/agriculture, according to local expert interviews. Hence, we separated the gajni land from the estuary for the purpose of the biome classification using the Sequential Maximum Angle Convex Cone (SMACC) tool, creating Endmembers. The 9th Endmember raster separated the estuary and aquaculture/gajni land and a mask was created containing the two.

We combined the SMACC tool output and the ocean and estuary masks to build a decision tree classifier (DTC) to limit the spatial and reflectance outliers. The original scene was reclassified using the DTC script. The inputs were defined as the following bands in the decision work flow (Figure 4). The final eight-biome image was assessed for accuracy using a confusion matrix, a simple way of presenting an accuracy assessment of a remotely sensed image [75]. The matrix separates errors of omission (i.e., Producer's Accuracy - the number of pixels correctly classified in a particular category as a percentage of the total number of pixels actually belonging to that category in the image) from errors of commission (i.e., User's Accuracy - the number of correctly classified pixels to the total number of pixels assigned to a particular category). The reference dataset was a systematic point grid of our ground-based observations and photointerpretation by local experts. The overall accuracy of the WorldView-3 imagery was $75 \%$ and the Landsat 8 imagery was $78 \%$.

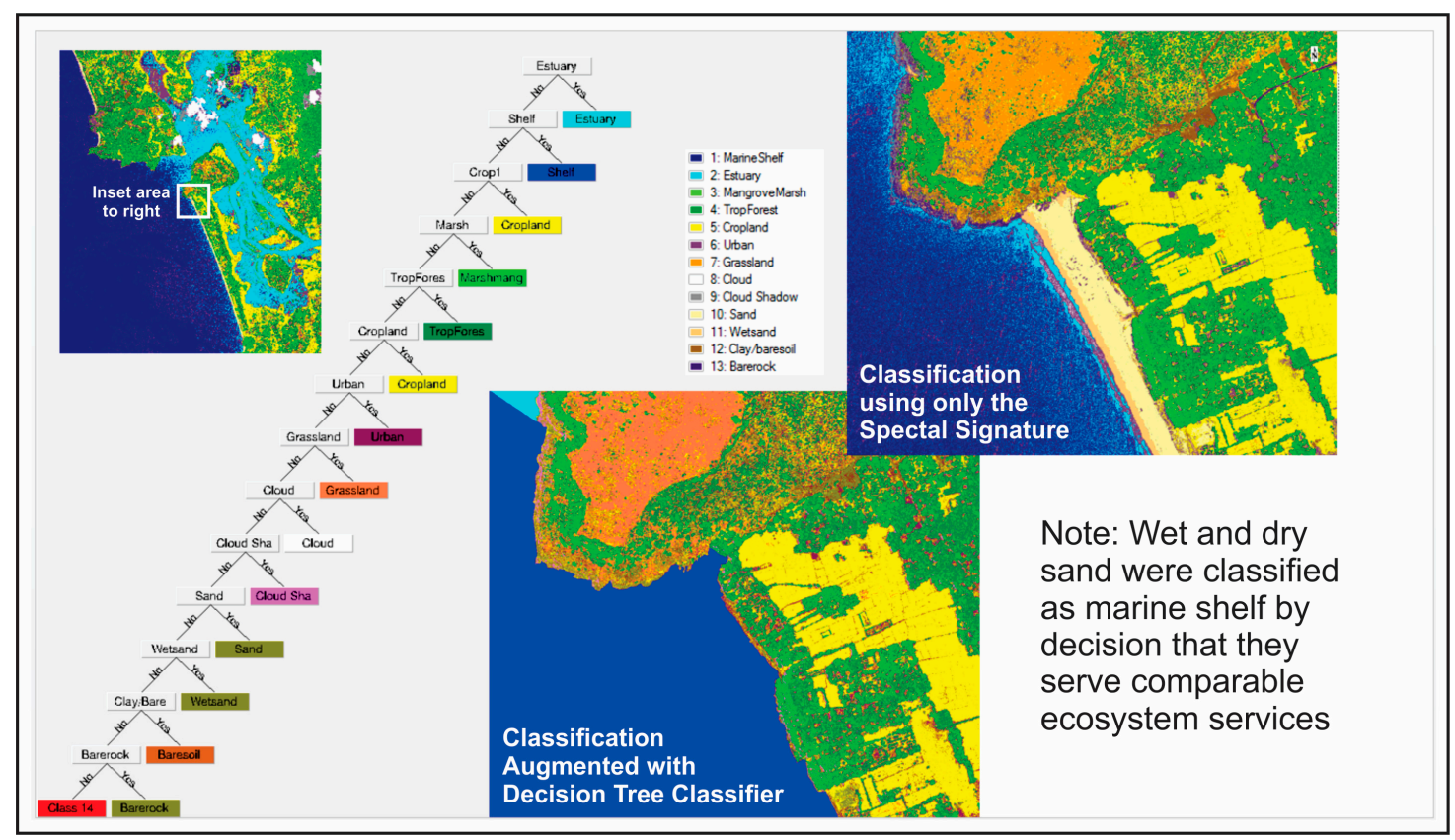

Figure 4. Spectral and decision tree classification of imagery.

\subsection{Benefit Transfer}

Following land-cover classification, we approximate ES dollar values for the eight land covers identified in the scenes. To the area land cover estimates, we applied the average per hectare biome values derived from more than 300 peer-reviewed studies in the TEEB database [69]. These are the same values used by Costanza et al. [15]. This method—known as benefit transfer-is a common method in ES valuation practice that applies biome or land-cover values obtained from studied or known areas to other unstudied areas [76-78]. Not surprisingly, benefit transfer as a value approximation method is more common in cases when producing values in situ is infeasible. In its most simple form, the benefit transfer method may use a single value for a single ES obtained in one place to approximate the same or a similar ES value in another. Often, however, benefit transfer relies on multiple valuations of multiple ES of multiple land-cover types to derive average values for different biomes (our method). This approach offers an inexpensive and efficient way to produce a first-pass estimate of the value of 
ES, which we believe has relevance in specific debates over sustainable environmental management and the evaluation of tradeoffs associated with "development" projects.

The benefit transfer method has limitations; "basic value transfer is a crude first approximation at best" [15] (p. 156). Benefit transfer carries forward measurement errors inherent in any primary study on which it relies, and should not replace methodical and meticulous on-the-ground study. We note, however, that more robust studies often still rely on estimates, approximations, models, simplifications or secondary valuations $[68,79]$. Meanwhile, local detailed studies in at least some cases prove to be consistent with simple benefit transfer estimates [80]. Of a more practical and pragmatic concern, meticulous economic valuation is a time-consuming and expensive process that is likely out of reach for many local actors in many places [81], especially Global South contexts such as India. Benefit transfer then offers a balance—one that must be carefully considered—between "purism and practicality" [82]. Moreover, in addition to overcoming time and funding restrictions, we aim to show with this paper that benefit transfer applications can explicitly surmount political closure of environmental debate over the impacts of "development" and other land-use and environmental change.

While we agree with the sentiments of Loomis and colleagues that it is important to separate credible from incredible approaches to ES valuation, this is easier said than done, as an estimate or method that is "credible" to one person is often "incredible" to another [83]. The more than 300 peer-reviewed studies in the TEEB database [69] produced value estimates for ecosystem services using a variety of methods including market value, avoided cost, hedonic pricing, replacement cost, and contingent valuation. All of these methods have biases, uncertainty, and errors, and few address the complex spatial dependence of ES [84].

\section{Results}

The classified image derived from the WorldView-3 image for the 200 square kilometers around the Aghanashini River estuary (Figure 5A) resulted in 8 land-cover biomes providing ES value to the area (cloud and cloud shadows were not included as biomes and not evaluated). The final classified image from the Landsat 8 imagery provided the same number of biome classes (Figure 5B).

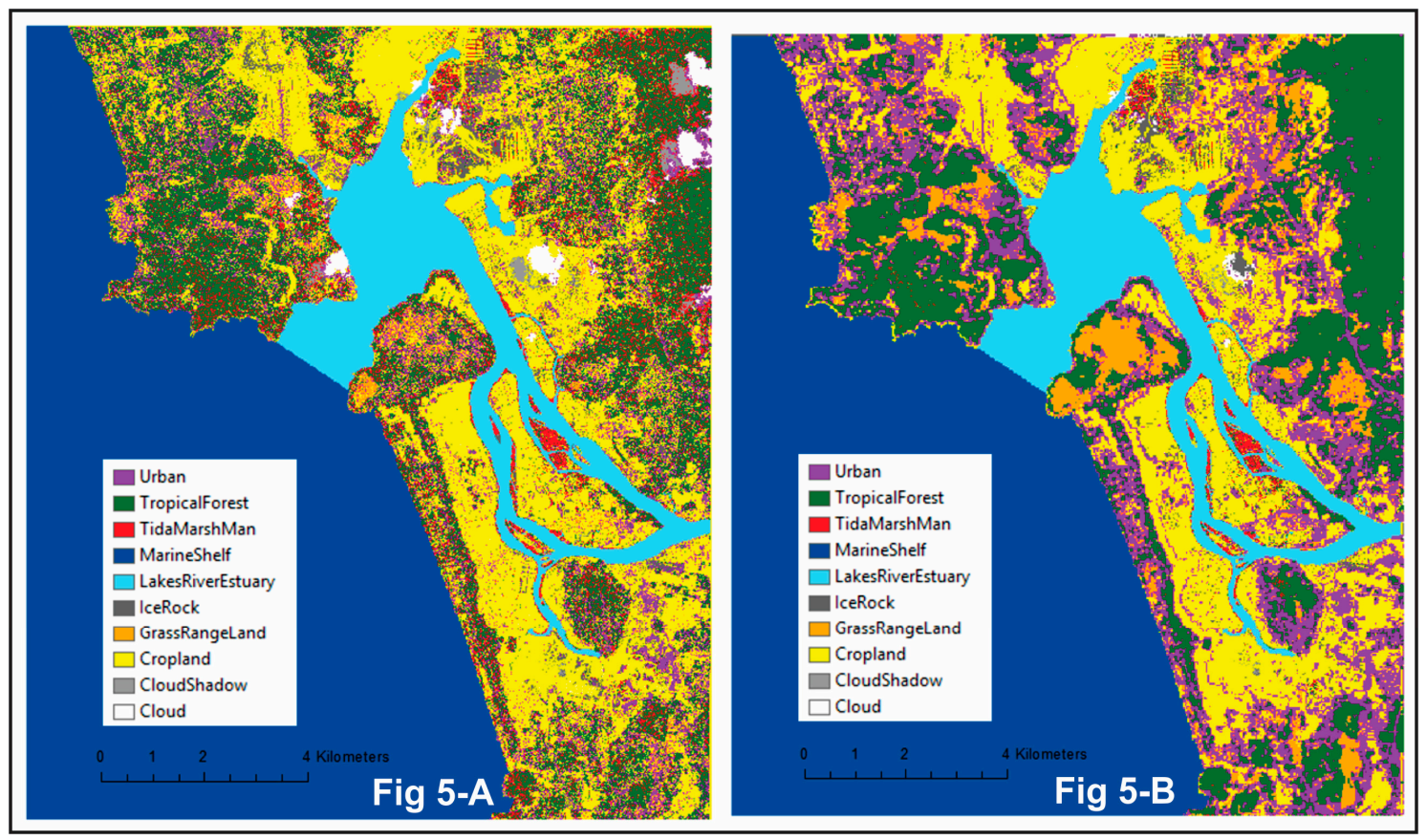

Figure 5. Final land cover classification: (A) results from WorldView-3; and (B) results from Landsat 8. 
The attribution of values to these two images resulted in a total annual ES estimated value of \$257 million per year (WorldView-3, Table 2) in 2007 dollars and \$298 million per year (Landsat 8, Table 3). These aggregate value estimates represent a mix of exchange and non-exchange values which accrue to various "users" at multiple scales.

Table 2. ES value estimates derived from classified WorldView-3 image.

\begin{tabular}{cccc}
\hline Land Cover/Biome & Area (Hectares) & $\begin{array}{c}\text { Value of ES per Hectare } \\
\text { (in 2007 US\$) }\end{array}$ & $\begin{array}{c}\text { Aggregate ES Value } \\
\text { (in 2007 US\$) }\end{array}$ \\
\hline Tidal/Marsh/Mangroves & 749 & 193,843 & $145,122,646$ \\
Urban & 1297 & 6661 & $8,636,490$ \\
Lake/River/Estuary & 1482 & 28,916 & $42,860,134$ \\
Cropland & 4297 & 5567 & $23,922,321$ \\
Tropical Forest & 3156 & 5382 & $16,987,894$ \\
Grass / Range Land & 237 & 4166 & 988,044 \\
Ice/Rock & 510 & 0 & 0 \\
Marine Shelf & 8448 & 2222 & $18,771,116$ \\
\hline & & TOTAL & $\mathbf{2 5 7 , 2 8 8 , 6 4 6}$ \\
\hline
\end{tabular}

Table 3. ES values estimates derived from classified Landsat 8 image.

\begin{tabular}{cccc}
\hline Land Cover/Biome & Area (Hectares) & $\begin{array}{c}\text { Value of ES per Hectare } \\
\text { (in 2007 US\$) }\end{array}$ & $\begin{array}{c}\text { Aggregate ES Value } \\
\text { (in 2007 US\$) }\end{array}$ \\
\hline Tidal/Marsh/Mangroves & 936 & 193,843 & $181,506,831$ \\
Urban & 2771 & 6661 & $18,454,700$ \\
Lake/River/Estuary & 1485 & 28,916 & $42,927,248$ \\
Cropland & 2763 & 5567 & $15,380,619$ \\
Tropical Forest & 3097 & 5382 & $16,669,453$ \\
Grass /Range Land & 955 & 4166 & $3,977,738$ \\
Ice/Rock & 117 & 0 & 0 \\
Marine Shelf & 8456 & 2222 & $18,788,321$ \\
\hline & & TOTAL & $\mathbf{2 9 7 , 7 0 4 , 9 1 1}$ \\
\hline
\end{tabular}

We intentionally do not produce error, ranges or standard deviation, lest we reinforce a notion that these values have fine precision. We are hardly alone in this stance [15]. Although the figures result in whole number dollar values, they remain coarse estimates that, as we argue below, constitute an important starting point for environmental politics, debate and discourse.

We note that ES valuation implicates spatial scale in multiple ways. First, global value estimates must rely on merging ES values and uses across spaces (and places) and times, mediated by politics, history, sociology, economy, etc.; we do not presume, for example, that the value-either quantitative or qualitative - of a mangrove ecosystem in Australia is fully equivalent to the value of mangroves in the Aghanashini River estuary.

Second, and similar, some but not all ES values vary within the scale of analysis. While the immediate exchange or use value associated with a discrete fishery harvest from the estuary may not change with the extent of analysis-i.e., the fish represent the same price when sold at the local dock or the same number of calories when consumed-other benefits such as carbon sequestration effectively accrue to populations far away from the mangroves. Those ES values may only be fully assessed at scales beyond the local.

Additionally, land-cover classification from more coarse-resolution imagery (more economical or free for larger extents of analysis) typically results in lower values [85] as high-value but rare biomes (e.g., mangrove wetlands) are often less visible in coarse-resolution imagery. However, in our case, we observed a decrease in calculated value at the higher resolution. The Landsat 8 image identifies more urban area (with an associated ES value of $\$ 6661$ per hectare per year), whereas 
the WorldView-3 imagery identified relatively more cropland (valued at $\$ 5567$ per hectare per year) (Figure 6). This partly results from land use patterns in this region where many small properties have multiple land cover types; at the $30 \mathrm{~m}$ spatial resolution of Landsat 8, many pixels that are a mix of roads, small gardens, field, tree plantations, and human settlements become identified as "urban." We note that this rural environment is fairly densely populated. More than 60,000 people live in villages bordering the river estuary alone, and we estimate more than 115,000 humans live in roughly 100 square kilometers of land in these images. This density would warrant the classification of "urban" in many schemes. The density also exceeds that of many urban-suburban metropolitan areas in the United States and Europe.

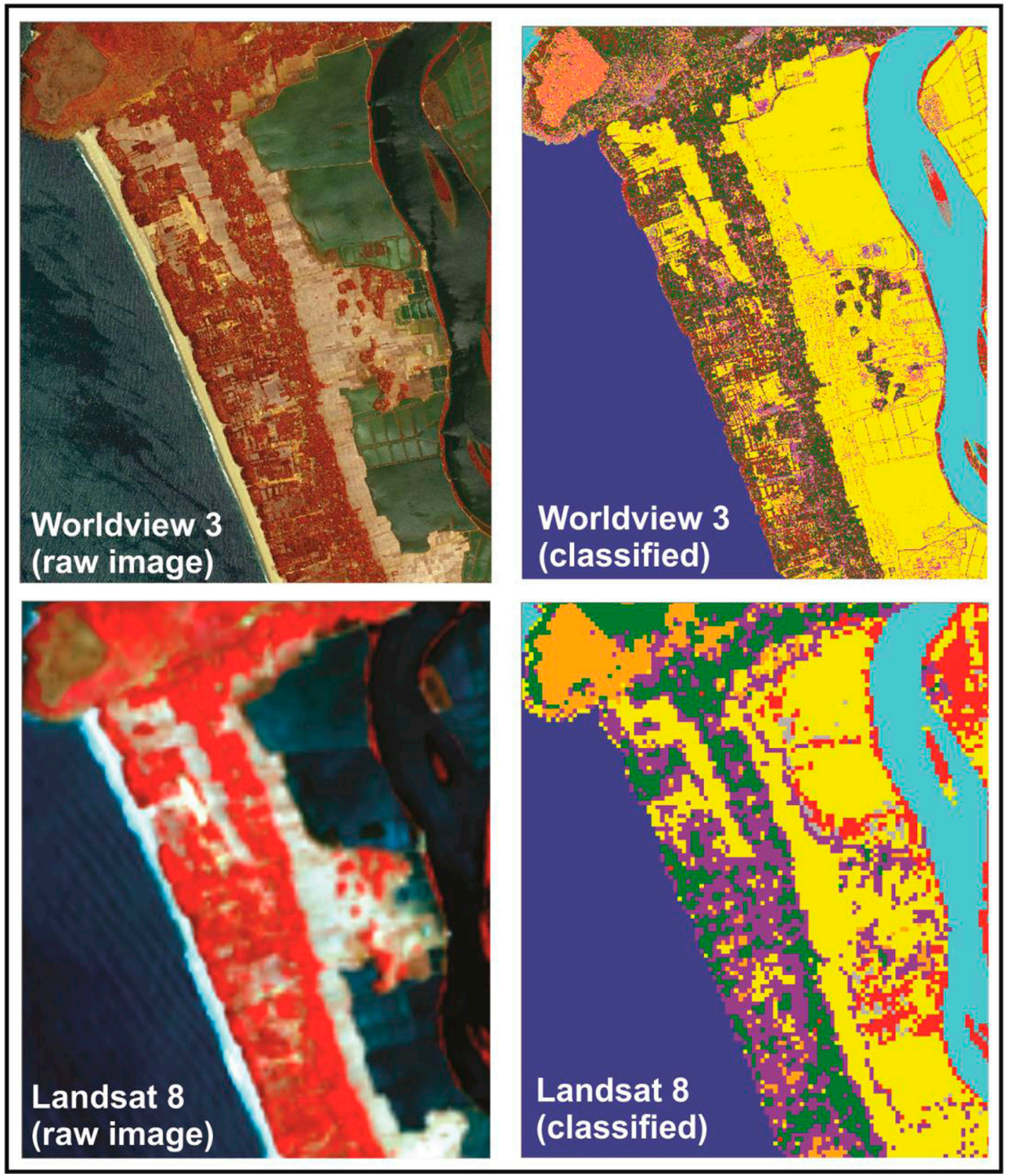

Figure 6. Effects of spatial resolution on classification. 


\section{Discussion}

The ES values reported here, though only estimates, do represent manifest local, regional and national exchange values, ranging from income earned in the tourist economy at local beaches (e.g., Om beach, a popular destination for tourists from across southwestern India) to the prices of fish sold in markets. For example, more than 2000 people around the estuary work in various livelihoods related to harvesting and sales of bivalves (oysters, clams and mussels) and their shells; according to one estimate, this slice of the local fishing economy generated Rs. 57.8 million in annual income in 2006 and 2007 (or about \$1.28 million) [55,86]. Other ES carry significant local non-exchange values, from subsistence food production to drinking water filtration. Local cultural values range from the traditions associated with fishing as heritage, boat building, so-called sacred mangroves and a river deity. Meanwhile, in line with the earlier discussion of scale, still other ES values accrue nationally and globally in the form of services such as biodiversity preservation and carbon sequestration. Many other monetary values - such as regulating services and supporting services provided by the coastal commons - are not automatically realized in any market. Indeed, many of these values represent ES that would only be priced if they were lost and replacements had to be bought (either by the state or individuals). Still others-particularly social, cultural and intrinsic values-may be impossible to price in any case.

Our ES value estimates remain just that-estimates. However, we certainly do not see them as dubious; they are derived from the hundreds of studies globally that constitute the TEEB database (including cases from India, our study's national context) [69]. Furthermore, in agreement with Costanza et al. [15], we believe more robust and rigorous study would find these values to be conservative estimates of the contribution that ES make to human and non-human well-being. While we understand that decision-makers often clamor for precision, a robust cost-benefit analysis for a particular compensation scheme or project is explicitly not our aim.

ES valuation suffers from a particular enduring problem in that ES present a combination of so-called market failures. ES are simultaneously public goods, common property and affected by both positive and negative externalities. They also, sometimes, have unclear and variable property rights in space and time. This is particularly true for the coastal and estuarine commons [87]. In addition, precise valuation of ecosystem services will always have to account for non-linear functions relating the spatial and temporal distribution of people, money, and the ecosystem services themselves. It is because of these sorts of complexities that assumptions of precision are problematic. For the same reason, we are not interested in making increasingly precise measures of ES value. Rather, we are interested in demonstrating that credible and defensible approximations of the value of ES (despite myriad uncertainties and errors that often cancel each other out) are in many cases so much larger than the value of the market economy that they can no longer be ignored or treated simply as trivial externalities that policy makers will eventually develop policies for internalizing. We present this valuation in the spirit that we need new institutions and environmental politics with broader visions of value in order to chart a path forward that is both sustainable and desirable.

Understanding that the ES values reported here are only estimates does not undermine their political import. We stress that ES and their values function as boundary objects, transcending narrow disciplinary concerns, methodological debates or limited policy utility. Our goal is to demonstrate the ways that these ES values, even as first-pass estimates, open up space for environmental political practice in the context of the proposed port that largely occludes consideration of ES. Policymakers who might dismiss these values or a transparent application of the benefit transfer approach risk ignoring what others have suggested amount to "good enough" [82] estimates of the relative importance of the contributions of ecosystems to human well-being.

These ES values, then, enter into political debates as they represent what might be sacrificed or preserved by "development" or environmental management. While many of these ES do not have an actual market price, real values of the environment are often discounted in a "development" discourse in India that privileges purported economic growth when evaluating projects, infrastructure etc.; the 
Aghanashini case provides a demonstrative example. For an imperfect comparison, then, consider that the state government calculated Gross Domestic Product of Kumta Taluk (the administrative territory encompassing the study area as well as the semi-urban nearby Kumta town) to be Rs. 3.6 billion or about $\$ 80$ million in 2005 [88]. Estuarine ES worth $\$ 257$ million (2011 values in 2007 dollars) dwarf the purely economic output of the entire taluk only six years prior.

Many of these ES values and benefits could be lost if the estuary is degraded or significantly altered (as would happen via the construction and operation of large industrial shipping port). Such changes would undermine the resilience and self-sufficiency of the local population, with unintended and challenging social and political conflict and tension resulting. This is a story that repeats widely across India and indeed the globe where ideological imperatives of development have overridden claims to both the quantitative and qualitative values of natural resources that accrue to local, regional, national and global citizens. Additionally, degrading regional biocapacity will have cascading effects in more distant geographies. For one, loss of ES that support livelihoods and wellbeing might only increase phenomena such as migration and internal displacement [89], part of what Sassen has termed "expulsions" [90]. Such environmental losses may also lead to worsening India's dependence on lands beyond national boundaries; India is currently one of many countries appropriating ecological assets internationally [91].

In attending to monetary ES values, we do not suggest dollar estimates are the only or best way to account for the importance of the environment. Diverse methods of valuing ecosystems are necessary; in the Aghanashini case, additional research into local social ecological traditions-without monetary valuation - would almost certainly raise other political questions about the use and abuse of nature. For example, local traditions include sacred patches of mangroves and, for some, worship of a river deity; more robust study and recognition of these value-laden practices could bring them into conversation with the shipping port development agenda which puts their material ecology-a functioning estuarine ecosystem - at risk. However, at present, the methods of economic measurement such as the above-quoted GDP statistics remain nearly hegemonic.

We feel the need to state again that we do not intend to serve capitalist exploitation or commodification of nature by creating inappropriate (possibly absurd) markets or specious prices. We see ES valuation not as inherently serving a neoliberal agenda but interrogating it, of asking what is to be given up in the name of certain kinds of "development" or what are the uses, benefits and potential losses (and for whom) of particular forms of environmental management. As such, we are attempting to wield ES valuation as a critical tool to make more legible the serious, uneven or hidden tradeoffs of "development". In the Aghanashini case, there remains no institutional mechanism to privatize and commodify many ES of the estuarine commons, but they presently fade to a zero-dollar value amid the "development" ideology in India.

\section{ES Valuation in Environmental Politics}

We conclude this paper with discussion about how this exercise and these ES value estimates can enter into environmental politics. We argue benefit transfer application can quickly produce rough estimates with potential impact in a variety of forums-from community organizing efforts to media to public hearings to court proceedings. Even if these values ultimately require more interpretation or are subjected to debate or criticism, the dialogue achieved, we argue, opens up space for environmental political practice. Here, we rely on several years of survey research, interviews and participant observation with Indian non-governmental organizations (NGOs) [52] as well as a shorter stint within an Indian government research institute by one of the authors. We note that our study occurred simultaneous to ongoing activism, conservation and development programming by multiple actors within the study site, including NGOs, government officials and private individuals and organizations.

Some local residents and officials have spoken out against the port project; the most vocal opposition has come from residents whose livelihoods depend specifically on estuarine goods and services (primarily fishing) highlighted by this analysis. For example, one fisher interviewed in March 
2016 was quick to recall other development projects including a power plant that have been opposed by the estuarine community because they would alter the local social ecology. "Of course, we'll fight this, too. This is our river. Our lives depend on this". In addition, environmental activists and scientists have also opposed the port and the larger development process. Many of these actors spoke at a public hearing in March 2015 and subsequently engaged in letter and report writing tactics, calling for additional study (and recognition) of the complex social ecology of the estuary. Even some officials within regional and state environmental bureaucracies have spoken against the project, though rarely in public.

However, a strong push remains underway by one arm of the state, coupled with private capital interests, to build the industrial port. A vocal segment of local residents-especially members of business communities who may possess the resources to benefit through secondary businesses eventually serving the port-have also spoken in favor of the port, echoing state officials who say the area and the nation need "development" and that some sacrifices must be made for that cause.

Even local supporters of the port express reservations about whether the promised benefits - primarily roads, some permanent managerial jobs, temporary construction jobs, and corporate social responsibility-centered "development" such as a hospital or financial compensation for lost natural resource livelihoods-will materialize. A local businessman involved in salt-panning said in a May 2015 interview, "We want this port because we deserve to see this development in our region. But we will make sure that we are compensated for any loss of livelihood. The fact is that this won't happen without our approval. And so we'll make sure they will bring benefits to us". We note that both the "they" and the "us" in that equation remain highly uncertain. As of writing of this article, corporate partners for construction and operation of the port-the entities who could ultimately be responsible for those benefits—remain unknown. Similarly, the ultimate design—which will determine which ecologies and ecosystem users are affected-has not been finalized.

Occurring in this context, our research serves to highlight the potential ES that are unevenly implicated in this development project. For example, ES associated with mangroves, mudflats and inundated croplands will all be affected by the port project, yet those differentiated values accrue to different users. Even our first-pass ecological baseline of land-cover and valuation for the estuary has not previously been published, so these explicit values have not factored outright in official debates over the port. We submit that these values have been ignored intentionally by a political process and "development" ideology that heavily discounts ES; for example, minutes of government meetings reveal that project proponents have claimed, in order to secure approvals, that fishing livelihoods dependent on mudflats and mangroves will not be disturbed [92]. These claims are contradicted by identification and specification of biomes and ES values that will be unquestionably degraded by the port. At the same time, these values have also not been available to local activists proposing alternatives of environmental protection and management [93].

Even first-pass ES valuation then offers a chance for more deliberate, grounded debate on the merits and impacts of the proposed project; identification of ES and their values (and subsequent users) can be another step toward the political project of recognizing and distinguishing demands of those who stand to gain from the port project as well as those might lose. We have attempted to disseminate our findings locally - presenting versions to local elected officials, activists and bureaucrats. Our goal in this effort is what we attempt to demonstrate in this paper: the wielding of ES valuation as an initial foray into environmental politics. Meetings where we have presented the results of this and other research have often turned into strategy sessions for how to marshal evidence regarding the consequences of port development. Some activists have also threatened lawsuits contesting port project government clearances on procedural grounds as well as on the contention that ES values (even without financial estimates) have been overlooked. One NGO has on multiple occasions called for "ammunition" from researcher-activist networks in what is expected to ultimately be a legal battle to challenge the data-poor basis for environmental clearance of the project. We do not seek to 
automatically be obstructionist, but rather we argue that ES valuation serves as a kind of heuristic "countermapping" $[94,95]$ and a starting point for environmental political praxis.

We earlier noted that environmental policy decisions in India are often made in a data-deficient environment; in the case of the proposed shipping port, one of us has argued, as an activist, that data is not only lacking but is intentionally left out through an official but gamed EIA process more akin to boosterism than critical evaluation. We quote at length a veteran local ecologist, who penned a 14-page letter to the government science commission that oversees the institute that produced EIA for the port project:

"It is very evident that either due to ignorance or design, the EIA team ... presented a seriously erroneous picture, particularly of the estuarine ecology and also biodiversity of the adjoining lands integral to the estuarine system. The team also failed to provide a convincing picture of the socio-economic implications on the community that would ensue the port execution. Yet, with all these glaring shortcomings in the EIA study, the proponents and the consultants were able to secure a favourable recommendation [from a government project review committee] for execution of the port project, which would amount to large scale destruction of the estuarine system and inflict serious livelihood consequences in the coastal zone" [96] (p. 12).

A more thorough review of potential degradation has been foreclosed, at least in part because of the expense of marshaling empirical data. One official within the state forest department-the agency in charge of protecting mangroves within the estuary-asked us on more than one occasion in 2016 for research on local relationships to mangroves; he said he was unable to devote funds and staff to such research precisely because of the inter-bureaucracy political climate in favor of port development. Indeed, the generation of primary data ES values for multiple of biomes with dozens of locally specific ES would be a massive undertaking requiring significant time and funding. Instead, this paper offers a case study of a relatively inexpensive method-possible even for NGO actors with minimal technical assistance - that quickly can bring more data into a conversation that should not end here. Our exercise is only a foundation for additional study. We further allow that such data need not only be used to block "development" projects like the port; rather, we argue that a more full-throated interrogation of the project—enabled in part by such ES study—could ultimately lead to additional environmental protections and democratic deliberation of the terms of "development", even if the project proceeds.

\section{Conclusions}

Finally, we return briefly to the criticism and debates of ES and valuation paradigms, which have received and deserve continued deliberation [13], not the least because of the possibility that valuation of ES may pave the way for commodification and/or seizure of ES by neoliberal agendas [21,22]. We suggest these values have economic (and therefore political) import; residents around the Aghanashini River estuary do indeed ascribe much tangible value-and, in some cases, specific market prices to- the ES that underpin their livelihoods and lifestyles. However, to suggest that these natures and natural resources have great value worth noting is not the same thing as seizing them in a "development" agenda that amounts to Harvey's notion of "accumulation by dispossession" [97]. Indeed, in the context of the Aghanashini River estuary and proposed industrial development, we see the exercise of ES valuation as quite the opposite, as a kind of engaged scholarship intended to provide evidence of what stands to be lost, who stands to lose it, and what perhaps deserves sustainable alternatives. Furthermore, far from ignoring critiques of the ES paradigm, we would also welcome intra- and inter-disciplinary engagement such that "critics of ES and neoliberal natures can find a useful solidarity with people engaged, through ES policy, in opposition to business-as-usual resource development" [35] (p. 773). Future study in the Aghanashini River estuary might attend to political ecological drivers of change in these ES values and their framing [36]. Our maps and ES values may also serve as a starting point to "address power relations more centrally" [98] (p. 134) in the ES 
approach by teasing apart to whom ES values (or losses) accrue and why. That would be a further step toward research-as-praxis, enabling environmental politics and fueling important conversations and debate among crucial actors-local, institutional, state, private and community—over the tradeoffs of "development" and the practices of sustainable environmental use or abuse.

Acknowledgments: WorldView-3 imagery is courtesy of a grant from the Digital Globe Foundation. Financial support for fieldwork was provided through a grant from the World Wide Fund for Nature-India; furthermore, the research would not be possible without the organizational and logistical support of Mangal Shetty, Panchabhuta Conservation Foundation and its research assistants. The School of Natural and Built Environments of the University of South Australia also provided funds towards the field campaign. Open Access publication made possible in part by support from the Berkeley Research Impact Initiative sponsored by the University of California at Berkeley library. We also express gratitude to Nathan Sayre and Michael Watts as well as the thoughtful anonymous reviewers who provided helpful feedback and comments.

Author Contributions: Adam Jadhav, Sharolyn Anderson and Paul Sutton conceived and designed the study. Adam Jadhav oversaw field research components while Sharolyn Anderson, Paul Sutton and Michael Dyer led the image analysis. All authors contributed to the discussion and writing in various amounts.

Conflicts of Interest: This research has been conducted in conjunction with the above affiliated/acknowledged NGOs and institutional sponsors. However, none except for the authors had control over the design of the study; in the collection, analyses, or interpretation of data; in the writing of the manuscript; or in the decision to publish the results.

\section{References and Notes}

1. Hansen, M.C.; Potapov, P.V.; Moore, R.; Hancher, M.; Turubanova, S.A.; Tyukavina, A.; Thau, D.; Stehman, S.V.; Goetz, S.J.; Loveland, T.R.; et al. High-resolution global maps of 21st-century forest cover change. Science 2013, 342, 850-853. [CrossRef] [PubMed]

2. Halpern, B.; Walbridge, S.; Selkoe, K.A.; Kappel, C.V.; Micheli, F.; D’Agrosa, C.; Bruno, J.F.; Casey, K.S.; Ebert, C.; Fox, H.E.; et al. A global map of human impact on marine ecosystems. Science 2008, 319, 948-952. [CrossRef] [PubMed]

3. Lambin, E.; Meyfroidt, P. Global land use change, economic globalization, and the looming land scarcity. Proc. Natl. Acad. Sci. USA 2011, 108, 3465-3472. [CrossRef] [PubMed]

4. Thomas, W.L. Man's Role in Changing the Face of the Earth; University of Chicago: Chicago, IL, USA, 1956.

5. Jha, C.S.; Dutt, C.B.S.; Bawa, S.K. Deforestation and land use changes in Western Ghats, India. Curr. Sci. 2000, 79, 231-238.

6. Foley, J.A.; DeFries, R.; Asner, G.P.; Barford, C.; Bonan, G.; Carpenter, S.R.; Chapin, F.S.; Coe, M.T.; Daily, G.C.; Gibbs, H.K.; et al. Global consequences of land use. Science 2005, 309, 570-574. [CrossRef] [PubMed]

7. Costanza, R.; d’Arge, R.; de Groot, R.; Farber, S.; Grasso, M.; Hannon, B.; Limburg, K.; Naeem, S.; O’Neill, R.; Paruelo, J.; et al. The value of the world's ecosystem services and natural capital. Nature 1997, 387, $253-260$. [CrossRef]

8. Daily, G. (Ed.) Nature's Services: Societal Dependence on Natural Ecosystems; Island Press: Washington, DC, USA, 1997.

9. Millennium Ecosystem Assessment (MEA). Ecosystems and Human Well-Being: Synthesis; Island Press: Washington, DC, USA, 2005.

10. Braat, L.; de Groot, R. The ecosystem services agenda: Bridging the worlds of natural science and economics, conservation and development, and public and private policy. Ecosyst. Serv. 2012, 1, 4-15. [CrossRef]

11. Kumar, P.; Martinez-Alier, J. The economic of ecosystem services and biodiversity: An international assessment. Econ. Political Wkly. 2011, 46, 76-80.

12. Abson, D.J.; von Wehrdena, H.; Baumgärtner, S.; Fischer, J.; Hanspach, J.; Härdtle, W.; Heinrichs, H.; Klein, A.M.; Langa, D.J.; Martens, P.; et al. Ecosystem services as a boundary object for sustainability. Ecol. Econ. 2014, 103, 29-37. [CrossRef]

13. Schröter, M.; van der Zanden, E.; van Oudenhoven, A.; Remme, R.; Serna-Chavez, H.; de Groot, R.; Opdam, P. Ecosystem services as a contested concept: A synthesis of critique and counter-arguments. Conserv. Lett. 2014, 7, 514-523. [CrossRef]

14. TEEB Synthesis. Mainstreaming the Economics of Nature: A Synthesis of the Approach, Conclusions and Recommendations of TEEB; Earthscan Publications Ltd.: London, UK; Washington, DC, USA, 2010. 
15. Costanza, R.; de Groot, R.; Sutton, P.; van der Ploeg, S.; Anderson, S.; Kubiszewski, I.; Farber, S.; Turner, R. Changes in the global value of ecosystem services. Glob. Environ. Chang. 2014, 26, 152-158. [CrossRef]

16. De Groot, R.; Brander, L.; van der Ploeg, S.; Costanza, R.; Bernard, F.; Braat, L.; Christie, M.; Crossman, N.; Ghermandi, A.; Hein, L.; et al. Global estimates of the value of ecosystems and their services in monetary units. Ecosyst. Serv. 2012, 1, 50-61. [CrossRef]

17. Barbier, E. Capitalizing on Nature: Ecosystems as Natural Assets; Cambridge University Press: Cambridge, UK, 2011.

18. Díaz, S.; Demissew, S.; Carabias, J.; Joly, C.; Lonsdale, M.; Ash, N.; Larigauderie, A.; Adhikari, J.R.; Arico, S.; Báldi, A.; et al. The IPBES Conceptual Framework-Connecting nature and people. Curr. Opin. Environ. Sustain. 2015, 14, 1-16. [CrossRef]

19. Díaz, S.; Demissew, S.; Joly, C.; Lonsdale, W.M.; Larigauderie, A. A Rosetta Stone for nature's benefits to people. PLoS Biol. 2015, 13, e1002040. [CrossRef] [PubMed]

20. Pascual, U.; Balvanera, P.; Díaz, S.; Pataki, G.; Roth, E.; Stenseke, M.; Watson, R.T.; Dessane, E.B.; Islar, M.; Kelemen, E.; et al. Valuing nature's contributions to people: The IPBES approach. Curr. Opin. Environ. Sustain. 2017, 26, 7-16. [CrossRef]

21. Heynen, N.; Robbins, P. The neoliberalization of nature: Governance, privatization, enclosure and valuation. Capital. Nat. Soc. 2005, 16, 5-8. [CrossRef]

22. Gómez-Baggethun, E.; Ruiz-Pérez, M. Economic valuation and the commodification of ecosystem services. Prog. Phys. Geogr. 2011, 35, 613-628. [CrossRef]

23. Spash, C. The new environmental pragmatists, pluralism and sustainability. Environ. Values 2009, 18, $253-256$. [CrossRef]

24. Neimeyer, S.; Spash, C. Environmental valuation analysis, public deliberation and their pragmatic synthesis: A critical appraisal. Environ. Plan. C Gov. Policy 2001, 19, 567-585. [CrossRef]

25. Vatn, A. The environment as a commodity. Environ. Values 2000, 9, 493-509. [CrossRef]

26. Spash, C.; Vatn, A. Transferring environmental value estimates: Issues and alternatives. Ecol. Econ. 2006, 60, 379-388. [CrossRef]

27. Das, S. The strange valuation of forests in India. Econ. Political Wkly. 2010, 45, 16-18.

28. De Groot, R.; Alkemade, R.; Braat, L.; Hein, L.; Willemen, L. Challenges in integrating the concept of ecosystem services and values in landscape planning, management and decision making. Ecol. Complex. 2010, 7, 260-272. [CrossRef]

29. Robbins, P. Fixed categories in a portable landscape: The causes and consequences of land-cover categorization. Environ. Plan. A 2001, 33, 161-179. [CrossRef]

30. Hejnowicz, A.P.; Rudd, M.A. The value landscape in ecosystem services: Value, value wherefore art thou value? Sustainability 2017, 9, 850. [CrossRef]

31. Castree, N. Neoliberalising nature: The logics of deregulation and reregulation. Environ. Plan. A 2008, 40, 131-152. [CrossRef]

32. Castree, N. Neoliberalising nature: Processes, effects, and evaluations. Environ. Plan. A 2008, 40, $153-173$. [CrossRef]

33. Walker, J. Bringing liquidity to life: Markets for ecosystem services and the new political economy of extinction. In Business Interests and the Environmental Crisis; Kohli, K., Menon, M., Eds.; Sage: New Delhi, India, 2016; pp. 3-27.

34. Bakker, K. The limits of 'neoliberal natures': Debating green neoliberalism. Prog. Hum. Geogr. 2010, 34, 715-735. [CrossRef]

35. Dempsey, J.; Robertson, M. Ecosystem services: Tensions, impurities, and points of engagement within neoliberalism. Prog. Hum. Geogr. 2012, 36, 758-779. [CrossRef]

36. Kull, C.A.; de Sartre, X.A.; Castro-Larrañaga, M. The political ecology of ecosystem services. Geoforum 2015, 61, 122-134. [CrossRef]

37. Norgaard, R. Ecosystem services: From eye-opening metaphor to complexity blinder. Ecol. Econ. 2010, 69, 1219-1227. [CrossRef]

38. Ostrom, E. Governing the Commons: The Evolution of Institutions for Collective Action; Cambridge University Press: Cambridge, UK, 1990.

39. Scott, J. Seeing Like a State: How Certain Schemes to Improve the Human Condition Have Failed; Yale University Press: New Haven, CT, USA, 1999. 
40. Thiemea, M.; Lehnera, B.; Abella, R.; Hamilton, S.K.; Kellndorferd, J.; Powella, G.; Riveros, J.C. Freshwater conservation planning in data-poor areas: An example from a remote Amazonian basin (Madre de Dios River, Peru and Bolivia). Biol. Conserv. 2007, 135, 484-501. [CrossRef]

41. Termorshuizen, J.; Opdam, P. Landscape services as a bridge between landscape ecology and sustainable development. Landsc. Ecol. 2009, 24, 1037-1052. [CrossRef]

42. Shrivastava, A.; Kothari, A. Churning the Earth: The Making of Global India; Penguin: New Delhi, India, 2012.

43. World Bank Disaster Management and Climate Change Unit. India Diagnostic Assessment of Selected Environmental Challenges: An Analysis of Physical and Monetary Losses of Environmental Health and Natural Resources; Report No. 70004-IN; World Bank: New Delhi, India, 2013; Volume 1.

44. Gadgil, M.; Guha, R. The Use and Abuse of Nature, Incorporating This Fissured Land: An Ecological History of India and Ecology and Equity; Oxford University Press: New Delhi, India, 2005.

45. Kurien, J. Are our seas up for grabs? Econ. Political Wkly. 2015, 50, 15-18.

46. Sridhar, A.; Menon, M.; Rodriguez, S. Coastal zone management: Better or bitter fare? Econ. Political Wkly. 2007, 42, 3838-3840.

47. Cook, I.; Bhatta, R.; Dinker, V. The multiple displacements of the Mangalore Special Economic Zone. Econ. Political Wkly. 2013, 48, 40-46.

48. Kundu, R.; Sahu, G. Selective inclusions and exclusions: Land-use planning and development in Ratnagiri. Econ. Political Wkly. 2014, 49, 69-76.

49. Robson, J.; Nayak, P. Rural out-migration and resource-dependent communities in Mexico and India. Popul. Environ. 2010, 32, 263-284. [CrossRef]

50. Chandran, M.; Mesta, P.; Boominathan, M.; Rao, G.; Vishnu, D.; Ramachandra, T. Aghanashini Estuary in Kumta Taluk, Uttara Kannada-Biological Heritage Site; ENVIS Technical Report No. 35; Indian Institute of Science Centre for Ecological Sciences: Bangalore, India, 2012.

51. Office of the Registrar General and Census Commissioner, India. Census of India. Primary Census Abstract 2011. Available online: http:/ / censusindia.gov.in (accessed on 17 April 2017).

52. Field observations and interviews come from extended participant observation, interviews conducted by a research team and other NGO research and conservation programming from January 2015 to July 2016.

53. Chandran, M.; Ramachandra, T.; Joshi, N.; Mesta, P.; Settur, B.; Vishnu, D. Conservation and Management of Mangroves in Uttara Kannada, Central Western Ghats; ENVIS Technical Report No. 50; Indian Institute of Science Centre for Ecological Sciences: Bangalore, India, 2012.

54. Bhat, M.; Nayak, V.; Chandran, M.; Ramachandra, T. Fish distribution dynamics in the Aghanashini estuary of Uttara Kannada, west coast of India. Curr. Sci. 2014, 106, 1739-1744.

55. Boominathan, M.; Chandran, M.; Ramachandra, T. Economic Valuation of Bivalves in the Aghanashini Estuary, West Coast, Karnataka; ENVIS Technical Report No. 30; Indian Institute of Science Centre for Ecological Sciences: Bangalore, India, 2008.

56. Rangarajan, M.; Sivaramakrishnan, K. (Eds.) India's Environmental History; Permanent Black: Ranikhet, India, 2012; Volumes 1 and 2.

57. Jadhav, A. Coastal development in Karnataka: Seeing neoliberalism through legal plural eyes. In Proceedings of the International Conference of the Commission on Legal Pluralism, Mumbai, India, 14-16 December 2015.

58. National Environmental Engineering Research Institute (NEERI). Environmental Impact Assessment Studies for Development of Sea Port at Tadadi, Karwar, Karnataka; Karnataka State Industrial and Infrastructure Development Corporate, Ltd.: Bangalore, India, 2012.

59. Jadhav, A. Place-based perceptions of estuarine conservation in India: “We don't threaten mangroves; mangroves threaten us". In Proceedings of the Annual Meeting of the American Association of Geographers, Boston, MA, USA, 21-25 April 2015.

60. Menon, M.; Kohli, K. A strange proposal to build Karnataka's largest port raises serious (and awkward) questions. Scroll.in, 22 March 2015. Available online: https://scroll.in/article/715364/ (accessed on 17 April 2017). 
61. Even as we write this paper, coastal development regulations were undergoing revisions by government technocrats that are widely seen as diluting protections of livelihoods and natural resources, further calling into question sustainable coastal development. Sinha, A.; Ranjan, A. "Govt plans to ease coastal rules, allow land reclamation for commercial use". The Indian Express, 22 March 2017. Available online: http:/ / indianexpress.com/article/india/govt-plans-to-ease-coastal-rules-allow-land-reclamationfor-commercial-use-4579820/s (accessed on 17 April 2017).

62. Ramesh, J. The two cultures revisited: The environment-development debate in India. Econ. Political Wkly. 2010, 45, 13-16.

63. ISRO. Coastal Zones of India; Indian Space Applications Centre: Ahmedabad, India, 2012.

64. For example, mapping projects and social ecology surveys by the National Centre for Sustainable Coastal Management, though mandated under Indian regulations and by courts for years, continue to be embroiled in ongoing controversies.

65. Badola, R.; Hussain, S. Valuing ecosystem functions: An empirical study on the storm protection function of Bhitarkanika mangrove ecosystem, India. Environ. Conserv. 2005, 32, 85-92. [CrossRef]

66. Lele, S.; Patil, I.; Badiger, S.; Menon, A.; Kumar, R. Forests, hydrological services, and agricultural Income: A case study from Mysore district of the Western Ghats of India. In Environmental Valuation in South Asia; Haque, A., Murty, M., Shyamsundar, P., Eds.; Cambridge University Press: Cambridge, UK, 2011; pp. 141-169.

67. Maharana, I.; Rai, S.; Sharma, E. Valuing ecotourism in a sacred lake of the Sikkim Himalaya, India. Environ. Conserv. 2000, 27, 269-277. [CrossRef]

68. Ghermandi, A.; Sheela, A.M.; Justus, J. Integrating similarity analysis and ecosystem service value transfer: Results from a tropical coastal wetland in India. Ecosyst. Serv. 2016, 22A, 73-82. [CrossRef]

69. TEEB Foundations. The Economics of Ecosystems and Biodiversity: Ecological and Economic Foundations; Earthscan Publications Ltd.: London, UK, 2010.

70. Kuppusamy, S.; Johnson, J.A.; Pande, A. Research gaps in coastal and marine conservation in India. In Coastal and Marine Protected Areas in India: Challenges and Way Forward; Sivakumar, K., Ed.; Wildlife Institute of India: Dehradun, India, 2013; pp. 230-241.

71. For example, he EIA for the Aghanashini port proposal put forward to a public hearing in 2015 contained outright plagiarism, lifting wholesale a policy and economic paper on bivalves in the estuary from scientists at the Indian Institute of Science, while still grossly under-estimating the number of fishers in the estuary.

72. Johannes, R.E. The case for data-less marine resource management: Examples from tropical nearshore finfisheries. TREE 1998, 13, 243-246. [CrossRef]

73. Kumar, M.; Saravanan, K.; Jayaraman, N. Mapping the coastal commons: Fisherfolk and the politics of coastal urbanization in Chennai. Econ. Political Wkly. 2014, 49, 46-53.

74. This high-resolution multi-spectral imagery was specifically provided by data grant from the Digital Globe Foundation.

75. Story, M.; Congalton, R. Accuracy Assessment: A user's perspective. Photogramm. Eng. Remote Sens. 1986, 52, 397-399.

76. Richardson, L.; Loomis, J.; Kroeger, T.; Casey, F. The role of benefit transfer in ecosystem service valuation. Ecol. Econ. 2015, 115, 51-58. [CrossRef]

77. Rosenberger, R.; Loomis, J. Benefit transfer. In A Primer on Nonmarket Valuation; Champ, P.A., Boyle, K.J., Brown, T.C., Eds.; Kluwer Academic Publishers: Boston, MA, USA, 2003; pp. 395-444.

78. Johnston, R.J.; Rosenberger, R. Methods, trends, and controversies in contemporary benefit transfer. J. Econ. Surv. 2010, 24, 479-510. [CrossRef]

79. Ninan, K.N.; Kontoleon, A. Valuing forest ecosystem services and disservices-Case study of a protected area in India. Ecosyst. Serv. 2016, 20, 1-14. [CrossRef]

80. Kubiszewski, I.; Costanza, R.; Dorji, P.; Thoennes, P.; Tshering, K. An initial estimate of the value of ecosystem services in Bhutan. Ecosyst. Serv. 2013, 3, e11-e21. [CrossRef]

81. Sangha, K.K.; Russell-Smith, J.; Morrison, S.; Costanza, R.; Edwards, A. Challenges for valuing ecosystem services from an Indigenous estate in northern Australia. Ecosyst. Serv. 2017, 25, 167-178. [CrossRef]

82. Bauer, D.; Johnston, R. The economics of rural and agricultural ecosystem services: Purism versus practicality. Agric. Resour. Econ. Rev. 2013, 42, 3-15. [CrossRef] 
83. Loomis, J.; Richardson, L.; Kroeger, T.; Casey, F. Valuing ecosystem services using benefit transfer: Separating credible and incredible approaches. In Valuing Ecosystem Services: Methodological Issues and Case Studies; Ninan, K.N., Ed.; Edward Elgar Publishing: Northampton, MA, USA, 2014; pp. 78-89.

84. Sutton, P. Space matters: Exploring problematic spatial issues in the valuation of ecosystem services. In Valuing Ecosystem Services: Methodological Issues and Case Studies; Ninan, K.N., Ed.; Edward Elgar Publishing: Northampton, MA, USA, 2014; pp. 132-147.

85. Konarska, K.; Sutton, P.; Castellon, M. Evaluating scale dependence of ecosystem service valuation: A comparison of NOAA-AVHRR and Landsat TM datasets. Ecol. Econ. 2002, 41, 491-507. [CrossRef]

86. Reserve Bank of India. Historical Exchange Rate Data. Available online: https://www.rbi.org.in/scripts / PublicationsView.aspx?id=15268 (accessed on 16 May 2017).

87. Barbier, E.; Hacker, S.; Kennedy, C.; Koch, E.; Stier, A.; Silliman, B. The value of estuarine and coastal ecosystem services. Ecol. Monogr. 2011, 81, 169-193. [CrossRef]

88. Government of Karnataka. Uttara Kannada District Human Development Report 2014; Planning, Programme Monitoring and Statistics Department: Bangalore, India, 2015.

89. Myers, N. Environmental refugees: A growing phenomenon of the 21st century. Philos. Trans. R. Soc. B 2002, 357, 609-613. [CrossRef] [PubMed]

90. Sassen, S. Explusions: Brutality and Complexity in the Global Economy; Belknap: Cambridge, UK, 2014.

91. Coscieme, L.; Pulselli, F.; Niccolucci, V.; Patrizi, N.; Sutton, P. Accounting for 'land-grabbing' from a biocapacity viewpoint. Sci. Total Environ. 2016, 539, 551-559. [CrossRef] [PubMed]

92. Government of Karnataka. Proceedings of the 10th Meeting of the Karnataka State Coastal Zone Management Authority; Government of Karnataka: Bangalor, India, 2015.

93. Hegde, B. Proposal for Declaration of Aghanashini Estuary as Critically Vulnerable Coastal Area (CVCA) under CRZ Notification 2011; Snehakunja Trust: Honnavar, India, 2014.

94. Peluso, N.L. Whose woods are these? Counter-mapping forest territories in Kalimantan, Indonesia. Antipode 1995, 27, 383-406. [CrossRef]

95. Harris, L.M.; Hazen, H.D. Power of maps: (Counter) mapping for conservation. ACME 2006, 4, 99-130.

96. Though the letter was delivered to officials in February 2017 and circulated among activists and researchers, we choose to provide the author the protection of anonymity under our own research ethics.

97. Harvey, D. The "new" imperialism: Accumulation by dispossession. Soc. Regist. 2004, 40, 63-87.

98. Berbés-Blázquez, M.; González, J.; Pascual, U. Towards an ecosystem services approach that addresses social power relations. Curr. Opin. Environ. Sustain. 2016, 19, 134-143. [CrossRef] 